\title{
PENGEMBANGAN MODEL MADRASAH INKLUSIF (Studi Atas Kesiapan Dan Model Pengembangan Kurikulum Madrasah Inklusif Mi Al-Hidayah Margorejo Surabaya)
}

\author{
Zumrotul Mukaffa \\ UIN Sunan Ampel Surabaya, Jawa Timur, Indonesia \\ zumrotul_mukaffa007@yahoo.com \\ Taufik \\ UIN Sunan Ampel Surabaya, Jawa Timur, Indonesia \\ taufiksiraj@uinsby.ac.id \\ M. Nuril Huda \\ UIN Sunan Ampel Surabaya, Jawa Timur, Indonesia \\ real_bjn80@yahoo.com
}

\begin{abstract}
THE DEVELOPMENT OF INCLUSIVE MADRASAH MODEL (A STUDY OF PREPAREDNESS AND DEVELOPMENT MODELS OF INCLUSIVE MADRASAH CURRICULUM IN MADRASAH IBTIDAIYAH AL HIDAYAH MARGOREJO SURABAYA). This research was motivated by the existence of learners in MI Al-Hidayah consisting of regular learners and learners with special needs. It was also conducted considering that in the city of Surabaya, inclusive madrasah model hasn't been found. This study aims to analyze the preparedness of madrasah towards inclusive madrasah, and to develop one of the products needed in the development of inclusive madrasah that is document product I of inclusive madrasah curriculum. This research used development research model. The results of the research were: first, 100\% or all respondents expressed
\end{abstract}




\title{
Zumrotul Mukaffa, Taufik, dan M. Nuril Huda
}

readiness to welcome the change from regular madrasah to inclusive madrasah as proved by the commitment to participate, promote, and avoid resistance to change. Second, document model I of the inclusive madrasah curriculum developed in Madrasah Al-Hidayah based on long term local needs analysis using four models: duplication model, modification, substitution and omission. The four, models are not contained in the curriculum document I MI Al-Hidayah. The four curriculum models will be clarified on the design of PPI, syllabus and RPP (Lesson Plan).

Keywords: Madrasah Ibtidaiyah, Inclusive, Curriculum.

\begin{abstract}
Abstrak
Penelitian ini dilatarbelakangi oleh keberadaan peserta didik di MI Al-Hidayah yang terdiri dari peserta didik regular dan peserta didik berkebutuhan khusus, dan juga dilatarbelakangi di wilayah Kota Surabaya model madrasah inklusif belum banyak ditemukan. Tujuan penelitian ini untuk menganalisis kesiapan madrasah menuju madrasah inklusif, dan mengembangakan salah satu produk yang dibutuhkan dalam pengembangan madrasah inklusif yaitu produk dokumen I kurikulum madrasah inklusif. Dalam prosesnya menggunakan model penelitian pengembangan. Hasil penelitian didapatkan: Pertama, $100 \%$ atau seluruh responden menyatakan siap menyambut perubahan dari madrasah reguler menjadi madrasah inklusif yang dibuktikan adanya komitmen berpartisipasi, mempromosikan, dan menghindari resistensi terhadap perubahan. Kedua, model dokumen I kurikulum madrasah inklusif yang dikembangkan di Madrasah Al-Hidayah berdasarkan analisis kebutuhan lokal yang dalam jangkan panjang menggunakan empat model yaitu model duplikasi, modifikasi, subsitusi dan omisi. Keempat model tersebut tidak tertuang pada dokumen kurikulum I MI Al-Hidayah. Keempat model kurikulum tersebut akan diperjelas pada desain PPI, silabus dan RPP.
\end{abstract}

Kata Kunci: Madrasah Ibtidaiyah, Inklusif, Kurikulum 


\section{A. Pendahuluan}

Semua warga Negara Indoneia berhak mendapatkan pendidikan yang layak tanpa terkecuali mereka yang memiliki kelainan fisik, emosional, mental, intelektual, dan/atau sosial, kecerdasan dan bakat istimewa maupun mereka yang tinggal di daerah terpencil atau terbelakang. Sebagaimana dalam Undang-Undang Sisdiknas Bab IV bagian kesatu Hak dan Kewajiban Warga Negara pasal 5 ayat 1, 2, 3 dan 4 dijelaskan bahwa;

Setiap warga negara mempunyai hak yang sama untuk memperoleh pendidikan yang bermutu. Warga negara yang memiliki kelainan fisik, emosional, mental, intelektual, dan/atau sosial berhak memperoleh pendidikan khusus. Warga negara di daerah terpencil atau terbelakang serta masyarakat adat yang terpencil berhak memperoleh pendidikan layanan khusus. Warga negara yang memiliki potensi kecerdasan dan bakat istimewa berhak memperoleh pendidikan khusus. (Permendiknas No. 70, 2009: 1-2).

Untuk mewujudkan penyelenggaraan pendidikan yang menghargai keanekaragaman, tidak diskriminatif, melayani semua kebutuhan peserta didik sebagaimana bunyi pasal di atas, maka diperlukan sebuah model pendidikan terpadu atau model pendidikan yang melayani peserta didik normal dan berkebutuhan khusus dalam satu lingkungan lembaga pendidikan. Model pendidikan yang seperti itu saat ini kita kenal dengan model pendidikan inklusif.

Model pendidikan inklusif adalah model pendidikan yang memberikan layanan kepada peserta didik berkebutuhan khusus untuk mengikuti proses pembelajaran bersama-sama dengan peserta didik yang normal dalam satu lingkungan pendidikan yang dikenal dengan sekolah inklusif. (Permendiknas No. 70, 2009: 1-2); (Nurdayanti Praktiningrum, 2010: 34)

Sekolah inklusif bukanlah Sekolah Luar Biasa yang mengekslusifkan peserta didik, namun sekolah inklusif adalah sekolah reguler yang juga menerima pesertra didik berkebutuhan khusus untuk belajar bersama dengan peserta didik yang normal 
(Isharwiti, 2010: 1). Model sekolah inklusif bertujuan untuk memberikan kesempatan kepada semua peserta didik yang memiliki kelainan fisik, emosional, mental, dan sosial atau memiliki potensi kecerdasan dan/atau bakat istimewa untuk memperoleh pendidikan yang bermutu sesuai dengan kebutuhan dan kemampuanya serta bertujuan untuk mewujudkan penyelenggaraan pendidikan yang menghargai keanekaragaman, menghapus diskriminatif dalam proses pendidikan.

Model sekolah inklusif merupakan hal baru di Indonesia, hal ini dibuktikan: Pertama, Peraturan Menteri Pendidikan Nasional Republik Indonesia No. 70 Tahun 2009 tentang pendidikan inklusif bagi peserta yang memiliki kelainan dan memiliki potensi kecerdasan dan atau bakat istimewa disahkan pada 5 Oktober 2009. Kedua, Peraturan Gubernur Jawa Timur No. 6 Tahun 2011 tentang penyelenggaraan pendidikan inklusif di Jawa Timur disahkan pada tanggal 25 Januari 2011. Ketiga, Peraturan Gubernur Jawa Barat No. 72 tahun 2013 tentang penyelenggaraan pendidikan inklusif disahkan pada tahun 2013. Keempat, Peraturan Gubernur Daerah Istimewa Yogyakarta No. 21 Tahun 2013 tentang penyelenggaraan pendidikan inklusif disahkan pada tanggal 15 Maret 2013. Kelima, kurikulum di negara kita belum didesain secara khusus untuk program pendidikan inklusif.

Selain bukti-bukti yang teruraikan di atas, berdasarkan pengamatan peneliti, bahwa lembaga pendidikan di Indonesia belum seluruhnya menyelenggrakan program pendidikan inklusif, hanya sebagian sekolah di Indonesia yang sudah menyelenggarakan pendidikan inklusif. Seperti halnya, di Surabaya pada tahun 2015 Dinas Pendidikan Kota Surabaya menyelenggarakan program inklusif hanya diselenggarakan di 50 SDN, 20 SMPN, 2 SMAN dan 2 SMKN. (http://ppdbsurabaya.net/umum/inklusif)

Sedangkan Sekolah Dasar Swasta di kota Surabaya yang menyelenggarakan program pendidikan inklusif hanya dapat dihitung oleh jari. Apalagi penyelenggaraan madrasah inklusif, di Kota Surabaya belum peneliti temukan sebuah lembaga Madrasah Ibtidaiyah yang 
sudah menyelenggarakan pendidikan inklusif secara terprogram sebagaimana Sekolah Dasar Negeri yang ada dibawah naungan Dinas Pendidikan Kota Surabaya (http://kkkmikotasurabaya. blogspot.com/2012/08/data-madrasah- ibtidaiyah-kota-surabaya. html). Padahal, seharusnya lembaga pendidikan Islam khususnya madrasah harus mengimplementasikan pendidikan inklusif lebih awal dibandingkan dengan sekolah-sekolah umum lainnya, karena dalam ajaran Agama Islam dalam Surat 'Abasa ayat 1-10 dijelaskan bahwa kita dilarang untuk mengabaikan seseorang yang cacat datang kepada kita untuk belajar suatu ilmu.

Dia (Muhammad) bermuka masam dan berpaling; karena telah datang seorang buta kepadanya; tahukah kamu barangkali ia ingin membersihkan dirinya (dari dosa); atau Dia (ingin) mendapatkan pengajaran, lalu pengajaran itu memberi manfaat kepadanya?;Adapun orang yang merasa dirinya serba cukup; Maka kamu melayaninya.; Padahal tidak ada (celaan) atasmu kalau Dia tidak membersihkan diri (beriman); dan Adapun orang yang datang kepadamu dengan bersegera (untuk mendapatkan pengajaran); sedang ia takut kepada (Allah); Maka kamu mengabaikannya.(Departemen Agama, 2010: 1024-1025)

Ayat di atas berkenaan dengan suatu peristiwa yang terjadi pada Nabi Muhammad yang pada saat itu didatangi seorang yang buta bernama Abdullah bin Ummi Maktum. Dia datang kepada Rasulullah S.A.W. meminta ajaran-ajaran tentang Islam; lalu Rasulullah S.A.W. bermuka masam dan berpaling daripadanya, karena beliau sedang menghadapi pembesar Quraisy dengan pengharapan agar pembesarpembesar tersebut mau masuk Islam. Maka turunlah surat ini sebagi teguran kepada Rasulullah (Qamaruddin Shaleh, dkk. 1998: 573- 574).

Berdasarkan landasan ayat di atas, maka dalam penelitian ini peneliti tertarik untuk mengembangkan model madrasah inklusif sebagai bentuk wujud pengamalan ajaran islam dalam bidang pendidikan. Penelitian ini akan peneliti lakukan di Madrasah Ibtidaiyah Al-Hidayah Jl. Margorejo Masjid No.3-E Wonocolo Surabaya. 
Menurut Kepala Sekolah Madrasah Ibtidaiyah Al-Hidayah, MI Al-Hidayah salah satu MI swasta di Surabaya yang didirikan sejak tahun 1972 namun pada saat ini masih berakreditasi B. Hal ini terjadi karena MI Al-Hidayah tergolong sebagai madrasah yang masih memiliki banyak kekurangan, misalnya: sarana prasarana yang belum memadai, manajerial yang kurang optimal, kurikulum yang belum tersusun secara baik dan benar, pendanaan yang tergolong dibawah rata-rata dan lain-lain.

Meskipun banyak kekurangan yang terdapat di madrasah AlHidayah, MI ini berani melayani peserta didik berkebutuhan khusus untuk belajar bersama dengan peserta didik reguler meskipun model pendidikan di madrasah ini tidak menerapkan program pendidikan inklusif. Hal ini dilakukan oleh pihak MI Al-Hidayah dikarenakan adanya keterbatasan jumlah peserta didik yang mendaftar di MI ini. Oleh sebab itu, agar tiap tahunnya memiliki peserta didik yang banyak, maka pihak MI tidak menolak siapapun yang mau bersekolah di madrasah ini, termasuk peserta didik yang berkebutuhan khusus dengan konsekuensi tenaga pendidik siap untuk membimbing peserta didik yang berkebutuhan khusus.

Berdasarkan uraian di atas, MI Al-Hidayah memiliki potensi sangat memungkinkan untuk menjadikan madrasah ini sebagai madrasah laboratorium pengembangan model madrasah inklusif dikarenakan dari ke- 68 peserta didik madrasah Al-Hidayah terdapat kurang lebih 5 (lima) peserta didik yang berkebutuhan khusus, dengan adanya ABK di MI Al-hidayah, para guru di MI Al-Hidayah memberikan pendampingan dan bimbingan khusus kepada peserta didik yang berkebutuhan khusus meskipun model pendidikannya bukan madrasah inkulusif. Berdasarkan alasan tersebut, maka dalam penelitian ini peneliti akan mengembangkan madrsah inklusif di MI Al-Hidayah Wonocolo Surabaya dengan alasan agar peserta didik berkebutuhan khusus yang berada di MI Al-Hidayah mendapatkan pelayanan pendidikan yang tepat berdasarkan kebutuhannya.

Rumusan masalah dalam penelituan ini yaitu: Pertama, bagaimanakan tingkat kesiapan penyelenggara tenaga pendidik 
dan kependidikan di Madrasah Ibtidaiyah Al-Hidayah Margorejo Surabaya dalam proses perubahan kelembagaan dari lembaga pendidikan reguler menjadi madrasah inklusif? Kedua, Bagaimana model pengembangan kurikulum madrasah inklusif di Madrasah Ibtidaiyah Al-Hidayah Wonocolo Surabaya?

Metode penelitian dalam penelitian ini menggunakan model penelitian pengembangan. Menurutnya, penelitian pengembangan merupakan jenis penelitian yang dilakukan dengan tujuan menghasilkan produk tertentu dan menguji keefektifan produk tersebut. (Sugiono, 2008: 407). Produk prototipe model Madrasah Ibtidaiyah Inklusif yang dipriorotaskan pada tahun pertama yaitu produk dokumen kurikulum (dokumen I), digunakan penelitian yang bersifat analisis kebutuhan. Oleh sebab itu, dalam model pengembangan ini menggunakan dua jenis metode penelitian, yaitu perpaduan antara metode kualitatif dengan metode kuantitatif atau yang dikenal dengan mixed method. Menurut John. W. Creswell yang dikutip oleh Sugiono dalam bukunya yang berjudul Metode Penelitian Kombinasi (Mixed Method) bahwa mixed method adalah pendekatan penelitian yang memadukan metode kualitatif dan kuantitatif dalam suatu kegiatan penelitian (Sugiono, 2013: 404)

Metode kualitatif digunakan dalam penelitian ini digunakan untuk mendeskripsikan konsep-konsep yang berkaitan dengan model madrasah yang dikembangkan di MI Al-Hidayah Margorejo Surabaya yang meliputi: bagaimana visi, misi dan tujuan lembaga, bagaimana model manajemen madrasah, model kurikulum madrasah inklusif, bagaimana karakteristik peserta didik yang ada di MI Al-Hidayah, bagaimana latar belakang peserta didik MI Al-Hidayah, bagaimana latar belakang orang tua peserta didik di MI Al-Hidayah, bagaiman sarana prasarana di MI Al-Hidayah, bagaimana model pembelajaran bagi peserta didik yang mengalami hambatan belajar. Sedangkan untuk metode kuantitatif diguanakan ketika peneliti mengetahui sampai dimana kesiapan Madrasah Ibtidaiyah Al-Hidayah untuk menyelenggarakan progarm madrasah inklusif. 


\section{B. Pembahasan}

\section{Madrasah Ibtidaiyah Inklusif}

Secara bahasa berasal dari Bahasa Inggris "inclusion" yang berarti termasuknya, pemasukan, pencantuman (John M. Enchols, Hassan Shadily, 2012:45). Sedangkan dalam Kamus Bahasa Indonesia, inklusif bermakna termasuk, semua, dan terhitung di dalamnya (Puis A. Partanto, M. Dahlan al-Barry, 2001: 257). Sedangkan secara istilah inklusif merupakan istilah terbaru yang dipergunakan untuk mendiskripsikan penyatuan bagi anak-anak berkebutuhan khusus ke dalam program-program pendidikan reguler. (J. Davit Smith, 2012: 45)

Madrasah secara etimologi merupakan isim makan dari kata "darasa" yang berarti belajar. Jadi, madrasah berarti tempat belajar bagi peserta didik (umat Islam) atau bangunan tempat pendidikan atau proses belajar mengajar secara formal dan klasikal.(Hans Wehr, 1980: 278). Secara istilah, madrasah adalah satuan pendidikan formal dalam binaan Menteri Agama yang menyelenggarakan pendidikan umum dengan kekhasaan agama Islam yang mencakup Raudhatul Athfal (RA), Madrasah Ibtidaiyah (MI), Madrasah Tsanawiyah (MTs), Madrasah Aliyah (MA),dan Madrasah Aliyah Kejuruan (MAK) Sedangkan Madrasah Ibtidaiyah (MI) adalah Satuan pendidikan formal yang menyelenggarakan pendidikan umum dengan kekhasan agama islam yang terdiri dari 6 (enam) tingkat pada jenjang pendidikan dasar. (Peraturan Menteri Agama Republik Indonesia No.90, 2013:3)

Pengertian Madrasah Ibtidaiyah jika disandingkan dengan pengertian inklusif berarti Madrasah Ibtidaiyah yang menyelenggarakan pendidikan dengan mengikutsertakan anak berkebutuhan khusus dan/atau mengalami hambatan dalam akses pendidikan untuk memperoleh pendidikan yang bermutu bersamasama dengan peserta didik pada umumnya. 


\section{Pengembangan Kurikulum Madrasah Inklusif}

Secara etimologi kurikulum berasal dari Bahasa Yunani yaitu curir yang berarti pelari dan curere yang berarti jarak yang harus ditempuh oleh pelari, dan berasal dari Bahasa Latin yaitu curriculum yang mengandung pengertian a running course. Selain dua bahasa tersebut, kurikulum juga berasal dari Bahasa Perancis yakni courier yang berarti to run. Istilah- istilah tersebut kemudian diadopsi ke dalam dunia pendidikan yaitu sejumlah mata pelajaran yang harus ditempuh untuk mencapai gelar dalam dunia pendidikan.(AlRasyidin, Samsul Nizar,2005: 55-56;Abdullah Idi, 1999: 3-4; M. Arifin,1991: 85).

Berkaitan dengan perkembangan ilmu pengetahuan dan kebutuhan dalam dunia pendidikan pengertian kurikulum di atas mengalami perubahan, yaitu kurikulum bukanlah hanya sebatas seperangkat mata pelajaran yang harus ditempuh peserta didik dalam tiap-tiap jenjang pendidikan, akan tetapi kurikulum adalah seperangkat pengalaman dan seluruh kegiatan yang dilakukan siswa baik di dalam maupun di luar sekolah dan kegiatan tersebut di bawah tanggung jawab sekolah atau juga dapat berarti seperangkat rencana dan pengaturan mengenai isi dan bahan pelajaran serta cara yang digunakan sebagai pedoman penyelenggaraan kegiatan belajar mengajar (Wina Sanjaya, 2008: 8; Nasution, 1995: 5). Adapun pengembangan kurikulum yaitu kegiatan menghasilkan kurikulum pada tingkat satuan pendidikan atau proses mengaitkan satu komponen kurikulum dengan yang lainnya untuk menghasilkan kurikulum. Pengembangan kurikulum juga bisa diartikan sebagai kegiatan penyusunan, pelaksanaan, penilaian, dan penyempurnaan kurikulum (Muhaimin,2005: 10)

Berdasarkan pengertian pengembangan kurikulum di atas, dapat dipahami bahwa pengembangan kurikulum Madrasah Ibtidaiyah inklusif berarti menyusun kurikulum madrasah sesuai dengan standar nasional pendidikan yang mengakomodasi kebutuhan, kemampuan, bakat, potensi dan minat peserta didik. 
Kurikulum Madrasah Ibtidaiyah inklusif pada dasarnya adalah menggunakan kurikulum reguler yang berlaku di sekolah umum yang pada saat ini adalah Kurikulum 13 atau yang disingkat K-13 . Namun karena peserta didik di Madrasah Ibtidaiyah Inklusif terdiri dari beragam karakteristik peserta didik yang antara lain terdiri dari peserta didik normal dan peserta didik berkebutuhan khusus dengan beragam hambatan, maka dalam implementasi di lapangan, kurikulum reguler yang diberlakukan di Madrasah Ibtidaiyah inklusif perlu dilakukan modifikasi sedemikian rupa sehingga sesuai dengan keragaman karakteristik peserta didik, kondisi daerah, dan jenjang serta jenis pendidikan, suku, budaya adat istiadat, serta status sosial ekonomi dan gender.

Model kurikulum Madrasah Ibtidaiyah inklusif, dikembangkan menjadi 4 model yaitu, duplikasi, modifikasi, substitusi, dan omisi. Pengembangan model tersebut disesuaikan dengan kebutuhan peserta didik, khususnya untuk peserta didik yang berkebutuhan khusus. Model duplikasi dikembangkan dan diberlakukan untuk siswa berkebutuhan khusus secara sama atau serupa dengan kurikulum yang digunakan untuk siswa pada umumnya (reguler). Dengan model kurikulum duplikasi ini, peserta didik yang berkebutuhan khusus menggunakan kurikulum yang sama seperti yang dipakai oleh anak-anak pada umumnya di sekolah reguler. Adapun model duplikasi ini diterapkan pada empat komponen, yaitu tujuan, isi, proses dan evaluasi.

Model Modifikasi merupakan pengembangan kurikulum 2013 yang diberlakukan untuk peserta didik reguler atau normal dilakukan penyesuaian dengan kemampuan peserta didik yang berkebutuhan khusus. Modifikasi kurikulum dapat diberlakukan pada empat komponen sebagaimana duplikasi, yaitu: Modifikasi Tujuan, Modifikasi Isi atau materi, Modifikasi Proses, dan Modifikasi Evaluasi. Modifikasi dapat dilakukan pada semua komponen atau salah satunya, menyesuaikan kebutuhan belajar siswa. Misalnya, modifikasi hanya dilakukan pada proses pembelajaran saja, sementara komponen tujuan, materi, dan evaluasi tidak. 
Model subsitusi adalah mengembangkan kurikulum dengan mengganti sesuatu yang ada dalam kurikulum umum dengan sesuatu yang lain. Penggantian dilakukan karena kurikulum tersebut tidak mungkin diberlakukan pada anak berkebutuhan khusus, tetapi diganti dengan kurikulum lainnya yang kurang lebih sepadan dengan kurikulum umumya. Model ini dapat diberlakukan juga pada empat komponen yaitu tujuan pembelajaran, materi dan proses serta evaluasi.

Model omisi dilakukan dengan cara menghilangkan suatu bagian atau keseluruhan kurikulum umum yang berlaku. Hal in dilakukan karena kurikulum umum tidak mungkin diterapkan pada siswa berkebutuhan khusus. Jadi, apa yang ada pada kurikulum umum tidak diberikan kepada anak yang berkebutuhan khusus, karena terlalu sulit atau tidak sesuai dengan kondisi siswa. Perbedaan kurikulum ini dengan subtitusi adalah jika dalam model subtitusi ada materi pengganti yang sepadan, sedangkan dalam model omisi tidak ada materi pengganti (Budiyanto, dkk, 2010: 75-77)

\section{Kesiapan Madrasah Ibtidaiyah Al-Hidayah}

a. Demografi Responden

Untuk mengurai tingkat kesiapan para pengelola $\mathrm{MI}$ AlHidayah, penelitian ini menggali informasi dari seluruh tenaga pendidik sejumlah 10 (sepuluh) orang sebagai responden. Ditinjau dari segi aspek gender, komposisi tenaga pendidik di madrasah adalah berimbang atau setara (lihat table 1)

Tabel 1

Komposisi Gender

Tenaga Pendidik di MI Al-Hidayah

\begin{tabular}{cccccc}
\hline & & Frequency & Percent & $\begin{array}{c}\text { Valid } \\
\text { Percent }\end{array}$ & $\begin{array}{c}\text { Cumulative } \\
\text { Percent }\end{array}$ \\
\hline Valid & Laki-Laki & 5 & 50,0 & 50,0 & 50,0 \\
\hline & Perempuan & 5 & 50,0 & 50,0 & 100,0 \\
\hline Total & 10 & 100,0 & 100,0 & \\
\hline
\end{tabular}

Sumber: Data Responden yang Diolah 
Tabel di atas menunjukkan, rasio pendidik di MI Al-Hidayah memiliki komposisi yang berimbang. Dari total 10 tenaga pendidik, 5 diantaranya atau equivalent dengan $50 \%$ dari total populasi merupakan laki-laki, dan nilai yang sama juga dimiliki oleh tenaga pendidik perempuan. Komposisi ini menjadi modal penting bagi proses perubahan organsiasi sekolah dari madrasah regular menuju madrasah inklusif. Prinsip dasar penyelenggaraan pendidikan inklusif yang tanpa diskriminasi, pada dasarnya telah diaksentuasikan di level penyelenggara sekolah.

Modal lain yang dimiliki oleh MI Al-Hidayah dalam menapaki perubahan kelembagaan adalah, kondisi tenaga pendidik yang masih dalam usia produktif. Data yang diperoleh menunjukkan, sebagian besar tenaga pendidik berusia antara 31-35 tahun (lihat gambar 1)

\section{Gambar 1}

Usia



Sebesar 5 tenaga pendidik (50\%) dari total keseluruhan pendidik di MI Al-Hidayah berusia antara 31-35 tahun, 3 orang (30\%) diantaranya berusia pada kisaran 25-20 tahun. Bahkan, salah satu guru masih cukup muda yakni berusia 23 tahun. Sedangkan, hanya 1 orang guru atau $1 \%$ dari total guru yang telah berumur antara 41-45 tahun.

Yang menjadi permasalahan, tenaga pendidik di MI AlHidayah memiliki pengalaman dalam dunia pendidikan yang hiterogen. Hal ini dapat dilihat dari masa kerja mereka yang cukup beragam (lihat gambar). 


\section{Gambar 2}

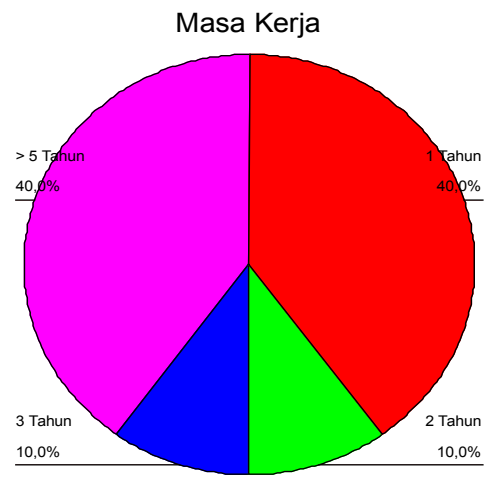

\section{Sumber: Data Responden yang Diolah}

Sebanyak 4 guru atau $40 \%$ dari total tenaga pendidik baru memiliki pengalaman dalam kegiatan pembelajaran kurang lebih satu tahun, 1 guru selama 2 tahun, dan tenaga pendidik yang memiliki pengalaman mengajar 3 tahun juga hanya 1 orang. Sedangkan yang memiliki pengalaman mengajar 5 tahun atau lebih hanya 4 orang atau kurang dari 50\% dari total tenaga pendidik yang ada.

Heteroginitas masa kerja yang dimiliki ternyata tidak mempengaruhi komitmen para guru dalam mensikapi perubahan yang hendak dilaksanakan di MI Al-Hidayah dari berstatus sebagai madrasah regular menjadi inklusif. Seluruh guru yang menjadi responden atau sebanyak 10 orang telah menyatakan mendapatkan informasi tentang perubahan tersebut, dan memberikan reaksi cukup positif.

b. Partisipasi Penyelenggara Sekolah

Secara garis besar, mereka mendapatkan informasi tentang perubahan dari dua sumber utama, yaitu: kepala sekolah dan Tim Peneliti. Namun yang menarik, justru informasi tentang adanya perubahan secara dominan didapatkan dari Tim Peneliti, bukan Kepala Sekolah MI Al-Hidayah (lihat table) 
Zumrotul Mukaffa, Taufik, dan M. Nuril Huda

Gambar 3

Sumber Informasi tentang Adanya Perubahan

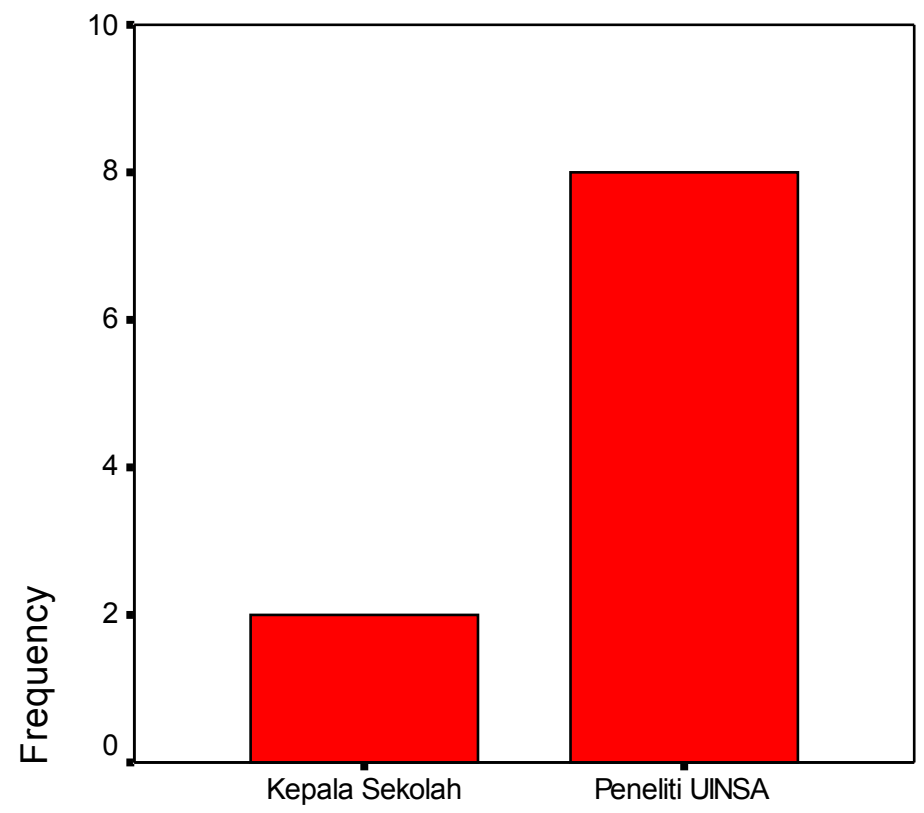

Sumber: Data Responden yang Diolah

Data di atas memberi petunjuk penting bahwa, peran para peneliti bukan saja hanya sekedar menggali, mengumpulkan, menganalisis, dan menyimpulkan informasi yang berhasil dikumpulkan terkait dengan focus penelitian mereka. Lebih dari itu, mereka berhasil menempatkan dirinya sebagai bagian penting dari pihak yang mendorong kearah perubahan kelembagaan madrasah menjadi inklusif, selain Kepala Sekolah.

Ketika digali lebih mendalam, apakah para guru tetap akan bertahan dan menjadi bagian dari MI Al-Hidayah, meskipun telah berubah menjadi madrasah inklusif, mereka secara keseluruhan menjawab "iya". Hanya saja, tindakan-tindakan apa yang hendak dilakukan, ketika tetap bertahan sebagai bagian dari tenaga pendidik madrasah, muncul jawaban berbeda. 


\section{Gambar.4}

Tindakan Nyata yang Hendak Dilakukan

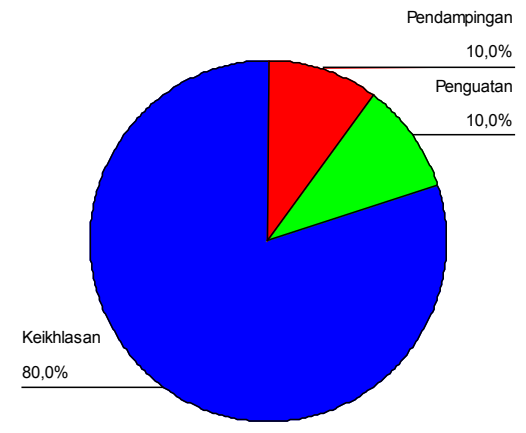

Data yang ada menunjukkan, terdapat komitmen kuat untuk menjaga partisipasi para guru di MI Al-Hidayah, meskipun telah berubah menjadi madrasah inklusif. Kesungguhan komitmen mereka ditunjukkan oleh keinginan mereka untuk menjaga dan mempertahankan keikhlasan dalam bekerja. Sebanyak 8 guru atau $80 \%$ dari total responden menegaskan bahwa, mereka tetap menjadi pendidik dengan penuh dedikasi, semangat, dan dibarengi oleh keikhlasan mendalam. Sementara satu guru yang memiliki keinginan kuat untuk serius dalam bekerja, terutama terkait dengan pendampingan anak berkebutuhan khusus ( $A B K)$, dan 1 guru lainnya lebih berkeinginan untuk mengembangkan pengetahuannya tentang sekolah inklusif.

Komitmen untuk berpartisipasi lebih aktif sebagai bagian dari kesiapan penyelenggara sekolah dengan bekerja lebih keras juga cukup mengemuka. Ketika ditanya, "apakah bersedia bekerja lebih keras lagi untuk mengefektifkan perubahan dari madrasah reguler menjadi madrasah inklusif", secara keseluruhan menjawab "iya" atau "bersedia". Komitmen mereka untuk lebih keras bekerja tersebut, dimanifestasikan kedalam berbagai bentuk, mulai dari pengembangan diri, melakukan bimbingan terhadap $A B K$ lebih efektif hingga mempersiapkan kegiatan pembelajaran yang relevan dengan kebutuhan (lihat tabel 2). 
Zumrotul Mukaffa, Taufik, dan M. Nuril Huda

Tabel 2

Bentuk Nyata Kerja Keras

\begin{tabular}{lcccc}
\hline \multicolumn{1}{c}{ Jenis kegiatan } & Frequency & Percent & $\begin{array}{c}\text { Valid } \\
\text { Percent }\end{array}$ & $\begin{array}{c}\text { Cumulative } \\
\text { Percent }\end{array}$ \\
\hline $\begin{array}{l}\text { Meningkatkan } \\
\text { Kualitas } \\
\text { Pembelajaran }\end{array}$ & 4 & 40,0 & 40,0 & 40,0 \\
\hline $\begin{array}{l}\text { Meningkatkan } \\
\text { Kapasitas Diri }\end{array}$ & 3 & 30,0 & 30,0 & 70,0 \\
\hline $\begin{array}{l}\text { Memberikan } \\
\text { Bimbingan Kepada } \\
\text { ABK }\end{array}$ & 2 & 20,0 & 20,0 & 90,0 \\
\hline $\begin{array}{l}\text { Meningkatkan } \\
\text { Kerja Sama dengan } \\
\text { Sesama Guru }\end{array}$ & 1 & 10,0 & 10,0 & 100,0 \\
\hline Total & 10 & 100,0 & 100,0 & \\
\hline
\end{tabular}

Sumber: Data Responden yang Diolah

Setidaknya terdapat empat manifestasi kerja keras yang hendak dilaksanakan oleh tenaga pendidik, ketika implementasi madrasah inklusif berlangsung. Sebanyak 4 tenaga pendidik (40\%) dari total responden menyatakan, mereka akan bekerja dalam bentuk meningkatkan kualitas pembelajaran. Sementara 3 tenaga pendidik (30\%) menegaskan peningkatan kapasitas diri sebagai bentuk kerja keras yang hendak dilakukan. Sedangkan 2 guru atau 20\% dari total responden memilih meningkatkan kerja-kerja bimbingan kepada peserta didik, dan 1 guru (10\%) lainnya akan bekerja keras dalam bentuk peningkatan kerja sama dengan sama guru di MI Al-Hidayah

c. Promosi terhadap Perubahan Menjadi Madrasah Inklusif

Satu tahapan penting untuk menuju pada promosi kelembagaan oleh guru atau tenaga pendidik di MI Al-Hidayah adalah, komitmen atau usaha serius para guru atau tenaga pendidik untuk menemukan ide-ide baru yang relevan dengan perubahan madrasah menjadi inklusif. Komitmen ini sangat kuat dikalangan tenaga pendidik atau para guru. Hal ini ditandai oleh jawaban mereka, ketika ditanya "apakah anda akan berusaha melahirkan ide-ide baru 
yang sejalan dengan perubahan sebagai upaya mengefektifkan kinerja madrasah", secara kesuluruhan mereka menjawab "iya".

Namun, jika ditelusuri lebih mendalam, ide-ide baru tersebut berkaitan erat dengan dua hal, yaitu: penataan ruang kelas dan pengembangan model pembelajaran yang relevan (lihat gambar).

\section{Gambar 5}

Bentuk-Bentuk Ide Baru



Ide baru terkait dengan pembelajaran paling banyak mendapatkan perhatian dari responden. Sebanyak 8 orang (80\%) dari total responden akan berusaha untuk mengembangkan modelmodel pembelajaran yang relevan dengan karakteristik peserta didik, sementara 2 guru lainnya atau $20 \%$ dari total responden lebih ingin berkreasi dalam penataan ruang kelas yang ramah terhadap $A B K$.

Sebagai bagian penting dari kesiapan penyelenggara madrasah adalah, perubahan cara kerja. Ketika ditanya, "apakah anda akan merubah cara kerja agar sejalan dengan upaya perubahan dalam rangka meningkatkan efektifitas kinerja di madrasah", secara keseluruhan responden menjawab "iya”. Bagaimana bentuk kongkrit dari perubahan cara kerja yang hendak dilakukan, masing-masing responden memiliki jawaban berbeda (lihat tabel). 
Zumrotul Mukaffa, Taufik, dan M. Nuril Huda

Tabel 3

Model Cara Kerja Baru Tenaga Pendidik

\begin{tabular}{lcccc}
\hline & Frequency & Percent & $\begin{array}{c}\text { Valid } \\
\text { Percent }\end{array}$ & $\begin{array}{c}\text { Cumulative } \\
\text { Percent }\end{array}$ \\
\hline Berperan Ganda & 1 & 10,0 & 10,0 & 10,0 \\
\hline Perubahan Perilaku & 1 & 10,0 & 10,0 & 20,0 \\
\hline $\begin{array}{l}\text { Merubah Model } \\
\text { Pembelajaran }\end{array}$ & 6 & 60,0 & 60,0 & 80,0 \\
\hline Penguatan Kapasitas & 2 & 20,0 & 20,0 & 100,0 \\
\hline Total & 10 & 100,0 & 100,0 & \\
\hline
\end{tabular}

Sumber: Data Responden yang Diolah

Secara garis besar, berdasarkan tabel di atas, perubahan cara kerja terkait dengan aspek perubahan peran, perubahan perilaku, pengembangan model pembelajaran, dan menambah pengetahuan yang dibutuhkan untuk dapat memperbaruhi cara kerja.

Selain merubah cara kerja melalui perubahan peran, sebagian responden ingin merubah cara kerjanya setelah terlebih dulu meningkatkan kapasitasnya sebagai guru sekolah inklusi, baik melalui pelatihan, diklat, workshop maupun kegiatan lain di luar sekolah. Terdapat dua responden (20\%) dari total populasi yang memberikan jawaban memperkuat lebih dulu kapasitasnya, sebelum melakukan perubahan cara kerja masing-masing.

Sementara responden yang ingin merubah cara kerjanya dengan fokus pada pengembangan model pembelajaran baru yang lebih relevan sebanyak 6 orang atau $60 \%$ dari total responden.

d. Resistensi Penyelenggara Madrasah

Resistensi atau penolakan secara diam-diam penyelenggara sekolah juga menjadi variabel penting dalam mensukseskan atau sebaliknya menggagalkan proses perubahan kelembagaan MI AlHidayah dari berstatus madrasah regular menjadi inklusif.

Potensi penolakan terhadap perubahan tidak ditemukan di kalangan tenaga pendidik maupun guru di MI Al-Hidayah. Hal ini dapat dilihat dari jawaban mereka terkait dengan faktor-faktor yang dapat menggagalkan pelaksanaan perubahan kelembagaan menjadi 
madrasah inklusif. Seluruh respon sebanyak 10 orang (100\%) menyatakan bahwa, mereka justru akan mengantisipasi keseluruhan aspek yang dapat menggagalkan upaya perubahan madrasah menjadi inklusif.

Selain itu, responden juga akan memberikan dukungan sepenuhnya terhadap pelaksanaan perubahan MI Al-Hidayah dari madrasah reguler menjadi inklusif. Ketika ditanya, "apakah anda akan memberikan dukungan sepenuhnya terhadap pelaksanaan perubahan di madrasah", maka secara keseluruhan (100\%) menjawab “iya”. Hal ini menunjukkan bahwa, tidak ada satu pun dari responden yang akan melakukan atau setidak-tidaknya memiliki sikap tidak mendukung terhadap perubahan menjadi madrasah inklusi.

Paparan data di atas memberi petunjuk penting bahwa, responden yang mewakili tenaga pendidik di MI Al-Hidayah memiliki kesiapan sangat tinggi untuk perubahan kelembagaan dari madrasah reguler menjadi madrasah inklusif. Hal ini ditandai oleh komitmennya untuk berpartisipasi, mempromosikan, dan menghindari resistensi terhadap perubahan. Untuk masing-masing variabel, ditemukan data bahwa, $100 \%$ atau seluruh responden menyatakan siap menyambut perubahan.

Dari data yang didapatkan juga menunjukkan tidak ada hubungan antara kesiapan berubah dengan usia tenaga pendidik atau guru yang menjadi responden. Hal ini berarti bahwa, kematangan emosional dan perbedaan pengalaman antara masing-masing tenaga pendidik tidak mempengaruhi kesiapannya mereka dalam menghadapi perubahan kelembagaan di MI Al-Hidayah.

Demikian pula, ditemukan perbedaan yang signifikan antara masa kerja dan kesiapan tenaga pendidik untuk berubah. Dalam penelitian ini diperoleh gambaran bahwa, nilai mean kesiapan tenaga pendidik untuk berubah cenderung sama pada tenaga pendidik antara yang memiliki masa kerja yang masih pendek dengan yang lebih lama. Dalam bahasa lain dapat dikatakan, tenaga pendidik yang masa kerjanya lebih sebentar akan memiliki kesiapan berubah yang sama tinggi dengan karyawan dengan masa kerja cukup lama. Dengan 


\section{Zumrotul Mukaffa, Taufik, dan M. Nuril Huda}

demikian, faktor situasional dan kontekstual, misalnya, ternyata tidak mempengaruhi cara pandang masing-masing tenaga pendidik, dalam pengertian bahwa, hubungan masa kerja dan kesiapan untuk berubah tidaklah bersifat situasional, dan konsekuensinya tidak akan mendapatkan hasil yang berbeda, meskipun dilakukan pada karakteristik sampel yang berbeda.

\section{Identifikasi Peserta Didik Madrasah Ibtidaiyah Al-Hidayah}

Madrasah Ibtidaiyah Al-Hidayah secara keseluruhan memiliki 57 (lima puluh tujuh) peserta didik. Berdasarkan hasil wawancara dengan Bu Chonik wali kelas IV, dari ke-57 orang peserta didik MI Al-Hidayah, ada 6 peserta didik yang mengalami hambatan belajar dan memerlukan pelayanan khusus. Akan tetapi, setelah diadakan pemeriksaan psikologi tentang taraf kecerdasan awal peserta didik MI Al-Hidayah, ditemukan lebih dari 6 orang peserta didik yang memerlukan pelayanan khusus yang diakaibatkan karena taraf kecerdasannya di bawah rata-rata. Oleh sebab itu, berdasarkan identifikasi awal yang dilakukan tim peneliti, dari ke-57 peserta didik yang berada di MI Al-Hidayah dibagi menjadi dua kelompok, yaitu kelompok pertama peserta didik reguler dan beberapa peserta didik yang memerlukan pelayanan khusus. Berdasarkan hasil pemeriksaan psikologi, ciri-ciri peserta didik yang memiliki taraf kecerdasan awal di bawah rata-rata yaitu:

a. Secara umum peserta didik agak kesulitan mengolah informasi dari lingkungan dan kesulitan untuk berpikir sistematis.

b. Peserta didik dapat melakukan pengamatan ruang dengan cukup baik namun cenderung kesulitan dalam memahami hubungan antara keseluruhan dan bagian serta berpikir analogi.

c. Peserta didik kesulitan dalam melakukan analisa sintesa untuk menghubungkan 2 atau lebih permasalahan yang serupa dan untuk memahami suatu prinsip untuk diterapkan dalam situasi berbeda.

d. Kesulitan untuk memahami suatu prinsip untuk diterapkan dalam situasi yang berbeda dan untuk mengamati hal-hal 
yang detail secara tajam dan berpikir dengan kritis untuk mengidentifikasi permasalahan.

e. Kesulitan dalam berfikir secara runtut dalam memahami rangkaian suatu permasalahan.

Selain taraf kecerdasan awal yang menjadi perhatian khusus pada identifikasi peserta didik MI Al-Hidayah, usia peserta didik juga menjadi fokus perhatian tim peneliti. Usia beberapa peserta didik MI Al-Hidayah seharusnya sudah melampaui batas maksimal usia peserta didik MI, hal ini disebabkan karena peserta didik mengalami hambatan dalam belajar. Berikut ini tabel usia rata-rata peserta didik MI sebagai berikut:

Tabel 4

Usia Rata-Rata Peserta Didik MI Al-Hidayah Margorejo

\begin{tabular}{|c|c|c|c|c|c|c|c|c|c|c|c|}
\hline \multicolumn{2}{|c|}{ Kelas I } & \multicolumn{2}{|c|}{ Kelas II } & \multicolumn{2}{|c|}{ Kelas III } & \multicolumn{2}{|c|}{ Kelas IV } & \multicolumn{2}{|c|}{ Kelas V } & \multicolumn{2}{|c|}{ Kelas VI } \\
\hline Min & Max & Min & Max & Min & Max & Min & Max & Min & Max & Min & Max \\
\hline 6 thn & 7 thn & 7 thn & 8 thn & 8 thn & 10 thn & 9 thn & 14 & 10 & 12 & 10 & 16 \\
\hline $2 \mathrm{bln}$ & $6 \mathrm{bln}$ & $6 \mathrm{bln}$ & $9 \mathrm{bln}$ & $2 \mathrm{bln}$ & 4 bln & & thn & thn & thn & thn 7 & thn 7 \\
\hline & & & & & & & & & 1 & bln & bln \\
\hline & & & & & & & & & bln & & \\
\hline
\end{tabular}

Jika merujuk pada Peraturan Menteri Agama Republik Indonesia No.90 Tahun 2013 Tentang Penyelenggaraan Pendidikan Madrasah Bagian Kedua (Madarsah Ibtidaiyah) pasal 14 dijelaskan bahwa usia peserta didik MI paleng rendah adalah 6 tahun, jika kurang dari 6 tahun maka harus ada rekomendasi tertulis dari psikolog atau dewan guru yang bersangkutan dan usia maksimal peserta didik MI yaitu 12 tahun. Maka jika memerhatikan tabel di atas, usia maksimal peserta didik di MI Al-Hidayah tidak sesuai dengan apa yang tertuang pada Peraturan Menteri Agama Republik Indonesia No.90 Tahun 2013 Tentang Penyelenggaraan Pendidikan Madrasah maksimal. Maka bagi peserta didik yang memiliki usia melebihi batas maksimal diperlukan pelayanan khusus, dan MI Al-Hidayah wajib memberikan pelayanan terhadap mereka yang mengalami hambatan, karena dalam Peraturan Menteri Agama Republik Indonesia No.90 Tahun 2013 Tentang Penyelenggaraan Pendidikan Madrasah dijelaskan bahwa MI wajib menyediakan akses bagi peserta didik berkebutuhan khusus. 


\section{Pengembangan Model Kurikulum}

Berdasarkan adanya kesiapan dan respon yang baik, produk dokumen I kurikulum madrasah inklusif Al-Hidayah Margorejo dikembangkan berbasis analisis kebutuhan dengan model Modifikasi. Kurikulum dikembangkan dengan memodifikasi kurikulum yang berlaku pada umumnya untuk peserta didik regular dengan yang berlaku untuk peserta didik yang berkebutuhan khusus. Berdasar hasil analisis kebutuhan, modifikasi dilakukan pada aspek indikator pembelajaran, tujuan pembelajaran, materi pembelajaran, proses pembelajaran, evaluasi pembelajaran, pengembangan diri dan program khusus ketunaan. Sedangkan Standar Kompetensi Lulusan (SKL), Kompetensi Inti (KI), dan Kompetensi Dasar (KD), tetap sesuai dengan Peraturan Menteri Agama RI No. 165 Tahun 2014 tentang Kurikulum 2013, dan Peraturan Menteri Pendidikan Nasional No. 57 tahun 2013 tentang Kurikulum 2013 Sekolah Dasar/Madrasah Ibtidaiyah. Kurikulum sebagaimana dimaksud memuat: BAB I: Pendahuluan (latar belakang, landasan hukum, sejarah singkat, visi, misi dan tujuan). BAB II: Standar Kompetensi (Standar Kompetensi Lulusan, Standar Kompetensi Lulusan Mata Pelajaran, Standar Kompetensi Muata Lokal, Pengembangan Diri. BAB III : Struktur Kurikulum dan Pengaturan Beban Belajar (Struktur Kurikulum, Pengaturan Beban Belajar dan Muatan Pembelajaran). BAB IV: Kriteria-Kriteria (Kriteria Ketuntasan Minimal, Kriteria Kenaikan Kelas, Kriteria Mutasi dan Kriteria Kelulusan Ujian Nasional dan Ujian Madrasah). BAB V. Kalender Pendidikan (Permulaan Tahun Pelajaran, Waktu belajar, Libur Sekolah, Jadwal Kegiatan dalam Kalender Pendidikan) dan lampiran-lampiran. Berikut ini salah satu bagian dari dokumen I kurikulum MI Al-Hidayah Margorejo. 
Pengembangan Model Madrasah Inklusif

Tabel 5

Beban Belajar dan Struktur Kurikulum

Madrasah Ibtidaiyah (MI) Al-Hidayah Margorejo Surabaya

Alokasi waktu

Mata Pelajaran

Belajar per-minggu

$\begin{array}{llllll}\text { I } & \text { II } & \text { III } & \text { IV } & \text { V } & \text { VI }\end{array}$

Kelompok A

1. Pendidikan Agama Islam

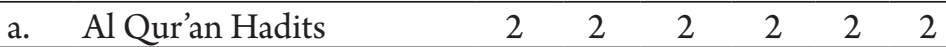

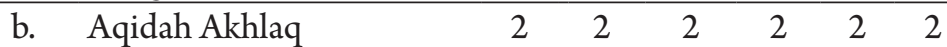

c. Fiqih 2 \begin{tabular}{llllll}
2 & 2 & 2 & 2 & 2 & 2 \\
\hline
\end{tabular}

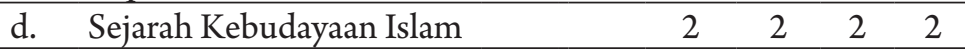

2.

$\begin{array}{lllllll}\text { Pendidikan Pancasila dan } & 5 & 5 & 6 & 5 & 5 & 5\end{array}$

Kewarganegaraan

\begin{tabular}{llllllll} 
3. & Bahasa Indonesia & 8 & 9 & 10 & 7 & 7 & 7 \\
\hline 4. & Bahasa Arab & 2 & 2 & 2 & 2 & 2 & 2 \\
\hline 5. & Matematika & 5 & 6 & 6 & 6 & 6 & 6 \\
\hline 6. & Ilmu Pengetahuan Alam & & & & 3 & 3 & 3 \\
\hline 7. & Ilmu Pengetahuan Sosial & & & & 3 & 3 & 3 \\
\hline
\end{tabular}

Kelompok B

\begin{tabular}{lllllll}
\hline 1. Seni Budaya dan Prakarya & 4 & 4 & 4 & 5 & 5 & 5 \\
\hline
\end{tabular}

2.


dan Kesehatan

Kelompok C

Program Khusus Ketunaan:

$\begin{array}{llllll}2 & 2 & 2 & 2 & 2 & 2\end{array}$

orientasi dan mobilitas, bina

komunikasi persepsi bunyi dan

irama, bina diri, Bina gerak dan

atau bina diri dan sosia, calistung

\section{Kelompok D}

\begin{tabular}{|c|c|c|c|c|c|c|c|}
\hline \multirow[b]{2}{*}{1.} & \multicolumn{7}{|l|}{ Muatan Lokal } \\
\hline & Bahasa Inggris & & & & 2 & 2 & \\
\hline & Bahasa Jawa & 2 & 2 & 2 & 2 & 2 & 2 \\
\hline
\end{tabular}

Kelompok E

\begin{tabular}{lllllll}
\hline Pengembangan Diri & 2 & 2 & 2 & 2 & 2 & 2 \\
\hline Standar Kecakapan Ubudiyah dan & 2 & 2 & 2 & 2 & 2 & 2
\end{tabular}

1. Akhlaq Mulia

\begin{tabular}{lllllll} 
Jumlah Alokasi Waktu Per Minggu & 42 & 44 & 48 & 53 & 53 & 53 \\
\hline
\end{tabular}


Zumrotul Mukaffa, Taufik, dan M. Nuril Huda

Implementasi dari dokumen tersebut, dapat dilihat modifikasinya pada salah satu contoh model modifikasi dalam pengembangan komponen Rencana Pelaksanaan Pembelajaran yang dikembangan oleh guru MI Al-Hidayah.

Tabel 6

Pengembangan Komponen Rencana Pelaksanaan Pembelajaran

\begin{tabular}{|c|c|c|}
\hline Komponen & Peserta didik regular & $\begin{array}{c}\text { Peserta Didik ABK } \\
\text { (Disleksia) }\end{array}$ \\
\hline Kompetensi Inti & $\begin{array}{l}\text { Memahami pengetahuan } \\
\text { faktual dengan cara } \\
\text { mengamati (mendengar, } \\
\text { melihat, membaca) dan } \\
\text { menanya berdasarkan } \\
\text { rasa ingin tahu tentang } \\
\text { dirinya, makhluk ciptaan } \\
\text { Tuhan dan kegiatannya, } \\
\text { dan benda-benda yang } \\
\text { dijumpainya di rumah dan } \\
\text { di sekolah }\end{array}$ & $\begin{array}{l}\text { Memahami pengetahuan } \\
\text { faktual dengan cara } \\
\text { mengamati (mendengar, } \\
\text { melihat, membaca) dan } \\
\text { menanya berdasarkan } \\
\text { rasa ingin tahu tentang } \\
\text { dirinya, makhluk ciptaan } \\
\text { Tuhan dan kegiatannya, } \\
\text { dan benda-benda yang } \\
\text { dijumpainya di rumah dan } \\
\text { di sekolah }\end{array}$ \\
\hline $\begin{array}{l}\text { Kompetensi } \\
\text { Dasar }\end{array}$ & Memahami tata cara wudu & Memahami tata cara wudu \\
\hline Indikator & $\begin{array}{l}\text { - Mengurutkan gambar } \\
\text { tata cara wudhu } \\
\text { - Menyebutkan urutan } \\
\text { tatacara wudhu secara } \\
\text { lisan } \\
\text { - Menghafalkan niat } \\
\text { wudhu } \\
\text { - Menuliskan urutan tata } \\
\text { cara wudhu }\end{array}$ & $\begin{array}{l}\text { - Mengurutkan gambar } \\
\text { tata cara wudhu } \\
\text { - Menyebutkan urutan } \\
\text { tatacara wudhu secara } \\
\text { lisan } \\
\text { - Menghafalkan niat } \\
\text { wudhu }\end{array}$ \\
\hline
\end{tabular}


Pengembangan Model Madrasah Inklusif

\begin{tabular}{|c|c|c|}
\hline $\begin{array}{l}\text { Tujuan } \\
\text { Pembelajaran }\end{array}$ & $\begin{array}{l}\text { - Setelah mengamati } \\
\text { gambar tata cara } \\
\text { wudhu, siswa mampu } \\
\text { mengurutkan gambar } \\
\text { tata cara wudhu secara } \\
\text { tepat } \\
\text { - Setelah mengurutkan } \\
\text { gambar, siswa mampu } \\
\text { menyebutkan tatacara } \\
\text { wudhu secara lisan } \\
\text { dengan berurutan } \\
\text { - Setelah mendengarkan } \\
\text { dan melihat video tata } \\
\text { cara wudhu, siswa } \\
\text { mampu melafalkan niat } \\
\text { wudhu secara lancar } \\
\text { - Setelah melihat video } \\
\text { tata cara wudhu, siswa } \\
\text { mampu menuliskan } \\
\text { urutan tata cara wudhu } \\
\text { secara tepat }\end{array}$ & $\begin{array}{l}\text { - Setelah mengamati } \\
\text { gambar tata cara } \\
\text { wudhu, siswa mampu } \\
\text { mengurutkan gambar } \\
\text { tata cara wudhu secara } \\
\text { tepat } \\
\text { - Setelah mengurutkan } \\
\text { gambar, siswa mampu } \\
\text { menyebutkan tata cara } \\
\text { wudhu secara lisan } \\
\text { dengan berurutan } \\
\text { - Setelah mendengarkan } \\
\text { dan melihat video tata } \\
\text { cara wudhu, siswa } \\
\text { mampu melafalkan niat } \\
\text { wudhu secara lancar }\end{array}$ \\
\hline $\begin{array}{l}\text { Materi } \\
\text { Pembelajaran }\end{array}$ & Tata cara wudhu & Tata c \\
\hline $\begin{array}{l}\text { Kegiatan } \\
\text { Pembelajaran }\end{array}$ & $\begin{array}{l}\text { - Mengidentifikasi gambar } \\
\text { tata cara wudhu } \\
\text { - Mengurutkan gambar } \\
\text { - Menonton video } \\
\text { - Membaca sumber belajar } \\
\text { (buku paket) } \\
\text { - Menulis tata cara wudhu }\end{array}$ & $\begin{array}{l}\text { - Mengidentifikasi } \\
\text { gambar tata cara wudhu } \\
\text { - Mengurutkan gambar } \\
\text { - Menonton video } \\
\text { - Mendengarkan teman } \\
\text { sebaya yang sedang } \\
\text { membaca } \\
\text { - Berlatih membaca tema } \\
\text { tentang tata cara wudhu }\end{array}$ \\
\hline $\begin{array}{l}\text { Evaluasi } \\
\text { Pembelajaran }\end{array}$ & $\begin{array}{l}\text { Tes tulis } \\
\text { Produk } \\
\text { Performance }\end{array}$ & $\begin{array}{l}\text { Produk } \\
\text { Perfomance }\end{array}$ \\
\hline $\begin{array}{l}\text { Pengembangan } \\
\text { diri }\end{array}$ & $\begin{array}{l}\text { Kecakapan Ubudiyah dan } \\
\text { Akhlaq Mulia }\end{array}$ & $\begin{array}{l}\text { Kecakapan Ubudiyah dan } \\
\text { Akhlaq Mulia }\end{array}$ \\
\hline $\begin{array}{l}\text { Program } \\
\text { Ketunaan }\end{array}$ & 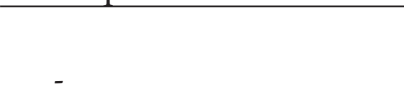 & $\begin{array}{l}\text { Baca Tulis Hitung } \\
\text { (Calistung) }\end{array}$ \\
\hline
\end{tabular}




\section{Simpulan}

Dilihat dari paparan data diatas dapat diambil kesimpulan, Pertama; Tingkat kesiapan penyelenggara pendidik dan tenaga kependidikan di Madrasah Ibtidaiyah Al-Hidayah Margorejo Surabaya dalam proses perubahan kelembagaan dari lembaga pendidikan reguler menjadi madrasah inklusif sangat tinggi. Hal ini ditandai oleh komitmennya untuk berpartisipasi, mempromosikan, dan menghindari resistensi terhadap perubahan. Untuk masingmasing variabel, ditemukan data bahwa, $100 \%$ atau seluruh responden menyatakan siap menyambut perubahan dari madrasah reguler menjadi madrasah inklusif.

Kedua; Model pengembangan kurikulum madrasah inklusif di Madrasah Ibtidaiyah Al-Hidayah Wonocolo Surabaya adalah Modifikasi. Modifikasi dilakukan pada Dokumen Rencana Pelaksanaan Pembelajan (RPP). Pengembangan ini dimulai dengan menentukan potensi dan masalah. Setelah pemetaan dilakukan dan dipastikan memiliki kesiapan, RPP modifikasi dikembangkan menyesuaikan kebutuhan khusus masing-masing peserta didik. 


\section{DAFTAR PUSTAKA}

Al-Rasyidin. Nizar,Samsul.2005. Filsafat Pendidikan Islam; Pendekatan Historis, Teoritis dan Praktis. Ciputat: PT. Ciputat Press.

Arifin, M. 1991. Filsafat Pendidikan Islam. Jakarta: Bumi Aksara.

Astuti, Idayu. 2011. Kepemimpinan Pembelajaran Sekolah Inklusif. Malang: Bayumedia Publishing.

Budiyanto, dkk, 2010. Modul Pelatihan Pendidikan Inklusif. Jakarta:

Kementerian Pendidikan Nasional.

Efendi, Mohammad. 2009. Pengantar Psikopedagogik Anak Berkelainan. Jakarta: Bumi Aksara.

Geniofam. 2010. Mengasuh dan Mensukseskan Anak Berkebutuhan Khusus. Jogyakarta: Garailmu.

Hamalik, Oemar. 2007. Dasar- dasar Pengembangan Kurikulum. Bandung: Remaja Rosdakarya.

Idi, Abdullah. 1999. Pengembangan Kurikulum Teori dan Praktek. Jakarta: Gaya Media Pratama.

Ishartiwi, Implementasi Pendidikan Inklusif Bagi Anak Berkebutuhan Khusus Dalam Sistem Persekolahan Nasional.Jurnal Pendidikan Khusus, Vol. 6, No. 2.

J.David, Smith. Sekolah Inklusif: Konsep dan Penerapan Pembelajaran, cet. ke-3 Bandung: Nuansa, 2012,. Terj. Denys, Ny.Enrica.

Lutfi, Atabik; Ahmad Zuhdi Muhdlor. 1997. Kamus Kontemporer Arab-Indonesia, Yogyakarta: Yayasan Ali Maksum Ponpes Krapyak Yogyakarta.

Muhaimin. 2005. Pengembangan kurikulum Pendidikan Agaman Islam; di Sekolah, Madrasah, dan Perguruan Tinggi. Jakarta: Raja Grafindo Persada.

Nasution. 1995. Kurikulum dan Pengajaran. Jakarta: Bumi Aksara.

Praktiningrum. 2010. Fonomena Penyelenggaran Pendidikan Inklusif Bagi Anak berkebutuhan Khusus. Jurnal Pendidikan Khusus, Vol.7. Nomor 2. 


\section{Zumrotul Mukaffa, Taufik, dan M. Nuril Huda}

Tim Prima Pena, Kamus Besar Bahasa Indonesia. Gita Media Press.

Thaha, Idris. al-Madrasah dalam Ensiklopedi Islam. Jakarta: Ichtiar Baru van Hoeve, 2005. Vol.3.

Sanjaya, Wina. 2008. Kurikulum dan Pembelajaran Teori Praktek Pengembangan KTSP. Jakarta: Kencana Prenada Media Group.

Shaleh, Qamaruddin; Dahlan A, dan Dahlan, M.D. 1998. Asbabun Nuzul;Latar Belakang Historis Turunnya Ayat-Ayat al-Qur'an. Bandung: CV. Diponegoro.

Stubbs, Sue. 2008. Inclusive Education Where There Are Few Resources. Oslo, Norway: The Atlas Alliance.

Subagyo Joko. 2004. Metode Penelitian Dalam Teori Dan Praktek. Jakarta: Rineka Cipta.

Sugiono. 2008. Metode Penelitian Pendidikan; Pendekatan Kuantitatif, Kualitatif dan R\&D. Bandung: Alfabet.

. 2013. Metode Penelitian Kombinasi (Mixed Method). Bandung: Alfabeta.

Team Media. 2006. Undang-Undang Republik Indonesia No. 23 Tahun 2002 tentang Perlindungan Anak. Surabaya: Media Centre.

Tim Redaksi Pustaka Setia. 2002. Undang-Undang Dasar 1945. Bandung: CV. Pustaka Setia.

Departemen Agama, Al-Qur'an Al-Karim dan Terjemahannya Ke Dalam Bahasa Indonesia. Jakarta: Departemen Agama.

Undang-Undang Republik Indonesia No. 4 Tahun 1997 tentang Penyandang Cacat

Peraturan Menteri Pendidikan Nasional NO. 22 Tahun 2006 Tentang Standar Isi

Peraturan Menteri Pendidikan dan Kebudayaan Republik Indonesia No.81A Tahun 2013 Tentang Implementasi Kurikulum

Peraturan Menteri Pendidikan dan Kebudayaan Republik Indonesia No.81A Tahun 2013 Tentang Implementasi Kurikulum Pedoman Pengembangan Muatan Lokal 
Pengembangan Model Madrasah Inklusif

Peraturan Menteri Pendidikan Nasional No. 70 tahun 2009 tentang Pendidikan Inklusif bagi Peserta Didik yang Memiliki Kelainan dan Memiliki Potensi Kecerdasan dan/atau Bakat Istimewa

Peraturan Menteri Pendidikan Nasional No.41 Tahun 2007 Tentang Standar Proses.

Undang-Undang Republik Indonesia No.20 Tahun 2003 tentang Sistem Pendidikan Nasional 
Zumrotul Mukaffa, Taufik, dan M. Nuril Huda

Halaman ini bukan sengaja untuk dikosongkan 